\begin{tabular}{l|c|c}
\hline ISSN: 0001-5113 & ACTA ADRIAT., & ORIGINAL SCIENTIFIC PAPER \\
AADRAY & 60(1): 53 - 60, 2019 & \\
\hline
\end{tabular}

\title{
Length-Weight relations and condition factor of roach Rutilus rutilus (Linnaeus, 1758) in Lake Volvi (Northern Greece)
}

\author{
Stavroula KYRITSI ${ }^{1 *}$ and Antonis K. KOKKINAKIS ${ }^{2}$ \\ ${ }^{1}$ Alexander Technological Educational Institute of Thessaloniki, School of Agricultural \\ Technology, Food Technology and Nutrition, Department of Agricultural Technology, Division \\ of Animal Production, 57400 Thessaloniki, Greece
}

${ }^{2}$ Aristotle University of Thessaloniki, Faculty of Forestry and Natural Environment, Laboratory of Wild Life and Freshwater Fisheries, Box 241, 54124 Thessaloniki, Greece

*Corresponding author, e-mail: stakir@ap.teithe.gr

Length-weight relations (LWRs) and different indices of condition factor for roach from Lake Volvi (Northern Greece) were estimated. Results showed that roach are heavier of a given length in Lake Volvi than in other areas worldwide, with females exhibited higher weight than males of the same length. Significant differences $(P<0.05)$ of LWRs were also exhibited between sexes depending on month. CLARK condition factor peaked at the end of summer displaying no significant difference between sexes, whereas the other three estimated condition factors (Allometric, FULTON, LE CREN) peaked in winter. The estimation of different proxies of condition factor disaggregated by sex might reduce the uncertainty raised by the estimation of fish growth.

Key words: seasonal variability, sex-specific, Fulton index, brackish water, Greece

\section{INTRODUCTION}

Length-weight relationship (LWR) is one of the most widely used and well documented method in fisheries research worldwide depending on many abiotic and biotic factors (i.e., seasonality, sex, size range, habitat, food availability and fishing pressure) (FROESE, 2006). The above relationship is also used as a proxy for fish condition (POPE \& KRUSE, 2001), based on the assumption that heavier fish of a given length are in better condition.

In this study, we estimated the LWRs for roach, in Lake Volvi (Northern Greece) by sea- son (monthly variability) and sex and we further explored different indices of condition factor. Although roach is one of the most abundant and commercially important species in Greek waters (ECONOMIDIS \& BANARESCU, 1991; ECONOMOU et al., 2007; BOBORI et al., 2010, 2017) and LWR for this species have been elsewhere presented (PAPAGEORGIOU, 1979; TSOUMANI et al., 2012; BOBORI et al., 2010, 2017; PETRIKI et al., 2010), neither LWR by sex and season nor different condition factor indices have been estimated in Greek and worldwide freshwaters. This is because most of the LWRs are derived from snapshot of annual samplings lacking sex disaggregation. In 
this context, the estimation of sex-specific condition factor might also reduce the uncertainty raised by the estimation of fish growth (POPE \& KRUSE, 2001).

\section{MATERIAL AND METHODS}

Roach samples were monthly collected from Lake Volvi (Northern Greece 40 $41^{\prime} \mathrm{N} 23^{\circ} 28^{\prime} \mathrm{E}$ ) using six separate panels of gill nets, with multiple mesh sizes of 16, 20, 24, 28, 34 and 40 mm from November 1997 to November 1998. Fish samples were separated per different mesh size and were placed in formaldehyde solution $(10 \%)$ until their laboratory analyses. The period between sampling and laboratory analyses never exceeded three days. For each fish sample were measured the total length (TL) in mm and total (W) and eviscerated weight (Wn) in $\mathrm{g}$.

The LWRs were determined according to the equation $\mathrm{W}=\mathrm{a} \times \mathrm{TL}^{\mathrm{b}}$ given by LE CREN (1951) where $a$ and $b$ are parameters of the LWR equation. These parameters were estimated by the least squares regressions method and, then, were log-transformed using the equation $\ln (\mathrm{W})$ $=\ln (\mathrm{a})+\mathrm{b} \times \ln (\mathrm{TL})$. The $\mathrm{b}$-value was tested by Student's t-test to verify if it was significantly different from the isometric growth $(\mathrm{b}=3, \mathrm{P}<$ 0.05) (FROESE et al., 2014). LWRs were separately estimated by season and sex and analysis of covariance (ANCOVA; ZAR, 1999) was used to test differences of the $\mathrm{b}$ values between season and sex.

Different indices of condition factors were also estimated; (a) LE CREN $\mathrm{K}_{1}=\mathrm{W} / \mathrm{W}_{\mathrm{e}}$, where $\mathrm{W}_{\mathrm{e}}$ is the predicted weight derived from the
LWR (LE CREN, 1951; WOOTTON, 1999), (b) Allometric $\mathrm{K}_{2}=\mathrm{W} / \mathrm{TL}^{\mathrm{b}} \cdot 10^{6}$ (RICKER, 1975; BOLGER \& CONNOLLY, 1989), (c) FULTON $\mathrm{K}_{3}=\mathrm{W} / \mathrm{TL}^{3} \cdot 10^{5}$ (BAGENAL \& TESCH, 1978) and (d) CLARK $\mathrm{K}_{4}=$ $\mathrm{Wn} / \mathrm{TL}^{\mathrm{b}} \cdot 10^{6}$ (WOOTTON, 1999). The indices (a) to (c) describe the variation of total weight and (d) the variation of the eviscerated weight. NIKOLSKY (1963) proposed the use of CLARK'S condition factor, because it better describes the fish physical condition without the influence of the maturity of gonads and of the stomach fullness.

\section{RESULTS AND DISCUSSION}

LWRs were highly significant $(\mathrm{P}<0.05)$ with $\mathrm{R}^{2}$ values being greater than 0.93 (Table 1). The mean annual value of the exponent $b$ for combined sexes was significantly (t-test, $\mathrm{P}<0.05)$ higher than 3 (3.684; $\mathrm{SD}=0.166)$. For between-sex comparison of $b$ values females exhibited significantly higher weight at specific length (ANCOVA, $\mathrm{P}<0.05$ ) than males of the same length $(b=3.700$ and 3.653 , respectively). With respect to seasons, LWRs were significantly positive allometric during winter, summer and autumn ( $\mathrm{t}$-test, $\mathrm{P}<0.05$ ), whereas this was not true for spring when LWR was significantly negative allometric (t-test, $\mathrm{P}<0.05$ ) (Table 2). The $b$ values ranged between 2.71 and 3.61 and were within the expected ones as reported in Fishbase (FROESE \& PAULY, 2016). Roach in Lake Volvi exhibited the highest $b$ values when compared to other ecosystems worldwide and in the same ecosystem in different period of time (i.e. PAPAGEORGIOU, 1979; TSOUMANI et al., 2012; BOBORI et al,. 2017) (Table 3), and thus, specimens

Table 1. Estimated parameters of length-weight relationships $\left(W=a T L^{b}\right.$, in $g$ and $\left.\mathrm{mm}\right)$ by sex and for combined sex for

Rutilus rutilus in Lake Volvi. $n$ is the sample size, min and max the minimum and maximum total length, $a$ and $b$ are the parameters of the $L-W$ relation and their standard errors $S E_{(a)}$ and $S E_{(b)}$ and $r^{2}$ is the coefficient of determination.

\begin{tabular}{|c|c|c|c|c|c|c|c|c|}
\hline & \multicolumn{3}{|c|}{ Total Length characteristics } & \multicolumn{5}{|c|}{ Parameters of the length-weight relationships } \\
\hline & $\mathrm{n}$ & $\min$ & $\max$ & $-\ln (\mathrm{a})$ & $\mathrm{SE}_{(\mathrm{a})}$ & $\mathrm{b}$ & $\mathrm{SE}_{(\mathrm{b})}$ & $\mathrm{r}^{2}$ \\
\hline Combined sex & 2439 & 91.5 & 220.3 & -14.820 & 0.081 & 3.684 & 0.166 & 0.95 \\
\hline Male & 444 & 92.5 & 183.5 & -14.660 & 0.231 & 3.653 & 0.048 & 0.93 \\
\hline Female & 1995 & 91.5 & 220.3 & -14.907 & 0.093 & 3.700 & 0.019 & 0.95 \\
\hline
\end{tabular}


Table 2. Estimated parameters of Length-Weight relationships ( $W=a T L^{b}$, in $g$ and $m m$ ), per season, per sex for Rutilus rutilus in Lake Volvi. $n$ is the sample size, min and max the minimum and maximum total length, $a$ and $b$ are the parameters of the $L-W$ relation and their standard errors $\left(S E_{(a)}\right.$ and $S E_{(b)}$ and $r^{2}$ is the coefficient of determination

\begin{tabular}{|c|c|c|c|c|c|c|c|c|}
\hline \multirow{3}{*}{ Season } & \multirow{3}{*}{$\mathrm{n}$} & \multicolumn{4}{|c|}{ L-W relationship } & \multirow[b]{2}{*}{$\mathrm{b}$} & \multirow[b]{2}{*}{$\mathrm{SD}_{(\mathrm{b})}$} & \multirow[b]{2}{*}{$r^{2}$} \\
\hline & & $\min$ & $\max$ & $-\ln (a)$ & $\mathrm{SD}_{(\mathrm{a})}$ & & & \\
\hline & & \multicolumn{7}{|c|}{ Combined sexes } \\
\hline Spring & 815 & 91.5 & 218.1 & -14.65 & 0.16 & 3.63 & 0.03 & 0.94 \\
\hline Summer & 726 & 96.5 & 190.0 & -13.92 & 0.12 & 3.51 & 0.02 & 0.96 \\
\hline Autumn & 617 & 98.0 & 220.0 & -13.36 & 0.12 & 3.40 & 0.02 & 0.97 \\
\hline \multirow[t]{2}{*}{ Winter } & 282 & 98.0 & 188.0 & -14.16 & 0.21 & 3.56 & 0.04 & 0.96 \\
\hline & & \multicolumn{7}{|c|}{ Male } \\
\hline Spring & 199 & 92.5 & 183.5 & -14.44 & 0.30 & 3.59 & 0.06 & 0.94 \\
\hline Summer & 120 & 97.0 & 160.0 & -9.57 & 0.87 & 2.66 & 0.18 & 0.64 \\
\hline Autumn & 103 & 98.0 & 171.5 & -12.77 & 0.38 & 3.27 & 0.08 & 0.95 \\
\hline \multirow[t]{2}{*}{ Winter } & 22 & 101.0 & 162.0 & -14.05 & 1.02 & 3.61 & 0.21 & 0.94 \\
\hline & & \multicolumn{7}{|c|}{ Female } \\
\hline Spring & 206 & 91.5 & 218.1 & -14.77 & 0.19 & 3.65 & 0.04 & 0.93 \\
\hline Summer & 606 & 96.5 & 190.0 & -10.97 & 0.29 & 2.95 & 0.06 & 0.80 \\
\hline Autumn & 514 & 101.0 & 220.0 & -13.58 & 0.19 & 3.44 & 0.04 & 0.94 \\
\hline Winter & 260 & 98.0 & 188.0 & -15.27 & 0.54 & 3.75 & 0.19 & 0.82 \\
\hline
\end{tabular}

were assumed to be heavier of a given length.

Differences in LWRs of roach among other studies could be attributed to one or more of the following factors (MOUTOPOULOS \& STERGIOU, 2002; FROESE, 2006; MATIĆ-SKOKO et al., 2011; TUTMAN et al., 2018): (a) differences in the number of specimens examined, (b) area/season effects, and (c) differences in the observed length ranges and the type of length used. Seasonal differences in LWR can be attributed to biological (e.g., reproduction, sex, food availability) and/or abiotic (e.g., water temperature) factors (WOOTTON, 1999; BOBORI et al,. 2010). Yet, the spawning and gonad activity might affect the seasonal variations in the $b$ values of the LWR. In the present study, $b$ values were significantly lower during summer than in other seasons due to spring spawning period of the roach in lake Volvi (March to April) (Table 2).

The temporal variation of the condition factor may be attributed either to reproduction or to nutrition/ecological issues (MURPHY et al,. 1991). Most of the estimated condition factors peaked in February one month before the reproduction (Fig. 1); $\mathrm{K}_{1}=1.11$ and, 1.13 for males and females; $\mathrm{K}_{2}=0.48$ and 0.38 , respectively; and $\mathrm{K}_{3}=1.25$ for females. Exceptions were $\mathrm{K}_{3}$ for males (1.17) that peaked one month earlier (January) and $\mathrm{K}_{4}$ that peaked in August (0.35 and 0.31 for males and females). LE CREN index was slightly decreased for both sexes during February-May, likely due to the energy costs during the reproduction (Fig. 1) (WOOTTON, 1999). During autumn and winter LE CREN 


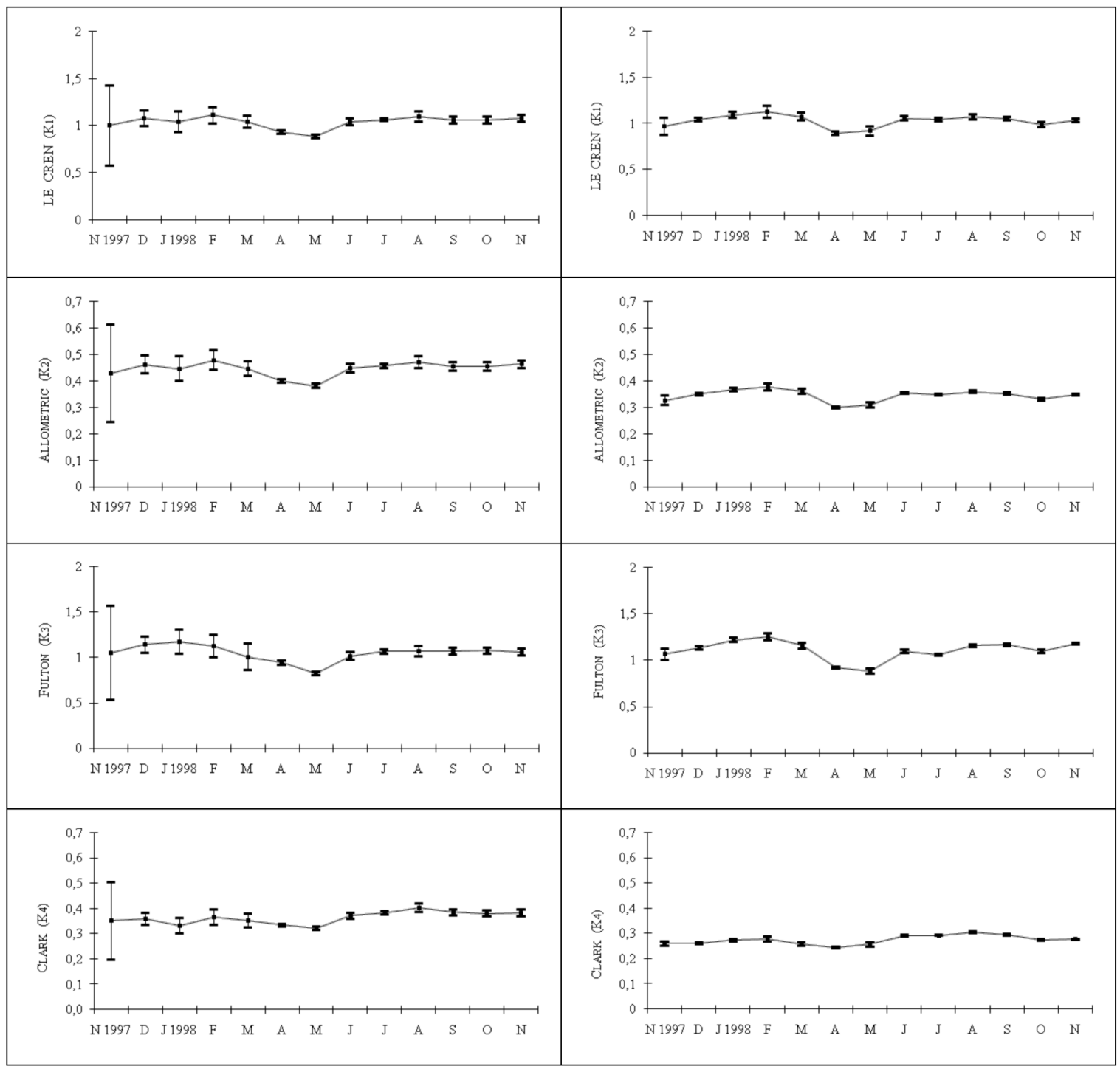

Fig. 1. Monthly variation (averages, 95\% C.I) of LE CREN $\left(K_{1}\right)$, Allometric $\left(K_{2}\right)$, FULTON $\left(K_{3}\right)$ and CLARK $\left(K_{4}\right)$ condition factors per sex, male (left) and female (right) of Rutilus rutilus in Lake Volvi

index also exhibited a considerable increase independently of sex, because of the increase of food availability (surplus of benthic organisms that is observed during these months; WOOTTON, 1999).

FULTON index (mean value 0.99 for males, 1.07 for females and 1.06 for both sex combined) exhibited the lowest values when compared to others studies conducted worldwide for roach; Lake Aydat: 1.65 and 1.57, for males and females (JAMET \& DESMOLLES, 1994); Sapanca: 1.11 and 1.17, respectively (TARKAN, 2006); Seyhan Dam: $1.472 \pm 0.24$ and $1.404 \pm 0.26$, respec- tively (ERGÜDEN et al., 2008), Błotno: 1.20, Sierakowo: 1.16, and Wapnickie: 1.25 for both sex combined (RACZYŃSKI et al., 2008). LE CREN and FULTON indices were higher in females than males (JAMET \& DESMOLLES, 1994), whereas the inverse was true for the Allometric and CLARK indices. This is because the Allometric and CLARK indices incorporate the value of the exponent $b$ of LWR, whereas, LE CREN and FULTON indices not. When the $b$ values were estimated independently of sex, the Allometric and CLARK indices were also exhibiting similar results compared with the corresponding ones 
Table 3. Estimates of coefficient b per sex of length-weight relationships of Rutilus rutilus from other ecosystems worldwide

\begin{tabular}{|c|c|c|c|c|c|}
\hline \multirow{2}{*}{ Area } & \multicolumn{3}{|c|}{$\begin{array}{c}\text { Regression coefficient } \\
\text { b }\end{array}$} & \multirow{2}{*}{$\begin{array}{l}\text { Length } \\
\text { type }\end{array}$} & \multirow{2}{*}{ Reference } \\
\hline & f & $\mathbf{m}$ & $\mathbf{f}+\mathbf{m}$ & & \\
\hline Southern England (Stour river) & 3.15 & 3.19 & - & FL & MANN 1973 \\
\hline \multirow[t]{2}{*}{ Southern England(Fromeriver) } & - & - & 3.30 & FL & MANN 1973 \\
\hline & 3.45 & 3.39 & - & FL & GOLDSPINK 1978 \\
\hline \multirow{3}{*}{ England (Rostherne lake)* } & 3.34 & 3.04 & - & FL & GOLDSPINK 1978 \\
\hline & 3.01 & 3.02 & - & FL & GOLDSPINK 1978 \\
\hline & 3.71 & - & - & FL & GOLDSPINK 1978 \\
\hline \multirow{7}{*}{ Netherland (Tjeukmeer lake)* } & 3.30 & 3.08 & - & FL & GOLDSPINK 1979 \\
\hline & 3.37 & 3.22 & - & FL & GOLDSPINK 1979 \\
\hline & 3.38 & 3.25 & - & FL & GOLDSPINK 1979 \\
\hline & 3.18 & 2.76 & - & FL & GOLDSPINK 1979 \\
\hline & 3.04 & - & - & FL & GOLDSPINK 1979 \\
\hline & 3.13 & - & - & FL & GOLDSPINK 1979 \\
\hline & 3.17 & - & - & FL & GOLDSPINK 1979 \\
\hline Greece (Volvi lake) & 3.61 & 3.40 & - & TL & PAPAGEORGIOU 1979 \\
\hline North Iran (Gomishan wetland) & 3.17 & 3.11 & - & TL & NADDAFI et al. (2005) \\
\hline North Iran (Anzali wetland) & 3.22 & 3.20 & - & TL & NADDAFI et al. (2005) \\
\hline Greece (Volvi lake) & - & - & 3.48 & TL & TSOUMANI et al.(2012) \\
\hline Greece (Chimaditida lake) & & & 3.27 & TL & TSOUMANI et al.(2012) \\
\hline Greece (Doirani lake) & & & 2.81 & $\mathrm{TL}$ & TSOUMANI et al.(2012) \\
\hline Greece (Kastoria lake) & & & 2.97 & $\mathrm{TL}$ & TSOUMANI et al.(2012) \\
\hline Greece (Petron lake) & & & 3.03 & TL & TSOUMANI et al.(2012) \\
\hline Greece (Vegoritida lake) & & & 3.01 & $\mathrm{TL}$ & TSOUMANI et al.(2012) \\
\hline Greece (Zazari lake) & & & 3.11 & TL & TSOUMANI et al.(2012) \\
\hline South-East Australia (Eildon lake) & 2.81 & 2.90 & 2.98 & FL & STOESSEL 2014 \\
\hline Greece (Volvi lake) & $\begin{array}{c}- \\
3.70\end{array}$ & $\begin{array}{c}- \\
3.65\end{array}$ & $\begin{array}{l}3.39 \\
3.68\end{array}$ & $\begin{array}{l}\mathrm{TL} \\
\mathrm{TL}\end{array}$ & $\begin{array}{l}\text { BOBORI et al. (2017) } \\
\text { Present study }\end{array}$ \\
\hline
\end{tabular}

* multiple measurements throughout the year; FL and TL are fork and total length of fish, respectively.

estimated by LE CREN and FULTON indices exhibited better condition for the females than for males (data not shown).

\section{CONCLUSIONS}

The knowledge of Length-Weight relationship (LWR) is one of the most widely used method in fisheries research, as a proxy for fish condition based on the assumption that heavier fish of a given length are in better condition (FROESE, 2006, POPE \& KRUSE, 2001). These results suggest that much of the observed variation among roach populations represent adaptations to local conditions and pressures. LE CREN and Fulton condition factors indices did not differ between sexes. However, in Allometric or CLARK indices prior knowledge of sex of roach would produce different condition factors between sexes in Lake Volvi. Consequently, differentiation of $\mathrm{b}$ values, between males and females, of Allometric and CLARK indices might reduce the bias produced in the estimation of fish condition. Moreover, the peak of CLARK's index condition factor in roach of Lake Volvi differentiate in terms of time with the other indices. 


\section{REFERENCES}

BAGENAL, T. B. \& F. W. TESCH. 1978. Age and growth. In: T.B. Bagenal, (Editor): Methods for assessment of fish production in freshwater, 3rd edition. Blackwell Scientific Publication, Oxford, U.K, pp 101-136.

BOBORI, D. C, D. K. MOUTOPOULOS, M. BEKRI, I. SALVARINA \& A. I. P. MUNOZ. 2010. Lengthweight relationships of freshwater fish species caught in three Greek lakes. J. of Biol. Res., 14: 219-224.

BOBORI, D. C., D. N. KANAKIS, O. PETRIKI \& A. C. TSIKLIRAS. 2017. Lake Morphometry and Trophic Status Affect Life-history Characteristics of Populations of Rutilus rutilus (L., 1758) (Cyprinidae) in Temperate Lakes. Acta Zool. Bulgarica, 69(3): 369-376.

BOLGER, T. \& P. L. CONNOLLY. 1989. The selection of suitable indices for measurement and analysis of fish condition. J. Fish Biol., 34: 171-182.

ECONOMIDIS, P. S. \& P. M. BANARESCU. 1991. The distribution and origins of freshwater fishes in the Balkan Peninsula, especially in Greece. Internationale Revue der gesamten Hydrobiologie und Hydrographie, 76: 257283.

ECONOMOU, A.N., S. GIAKOUMI, L. VARDAKAS, R. BARBIERI, M. STOUMBOUDI \& S. ZOGARIS. 2007. The freshwater ichthyofauna of Greece - an update based on a hydrographic basin survey. Medit. Marine Sci., 8(1): 91-166.

ERGÜDEN, S. A., D. ERGÜDEN, Z. MÜNIR \& L. GÖKSU. 2008. Growth Properties of Roach (Rutilus rutilus L., 1758) in Seyhan Dam Lake (Adana). J. Fisheries Scien., 2(1): 77-87.

FROESE, R. 2006. Cube law, condition factor and weight length relationships: history, metaanalysis and recommendations. J. Appl. Ichth., 22: 241-253.

FROESE, R., J. T. THORSON \& R. B. REYES. 2014. A Bayesian approach for estimating lengthweight relationships in fishes. J. Appl. Ichth., 30: 78-85.

FROESE, R. \& D. PAULY. 2016. 'FishBase. World Wide Web electronic publication'. Available at http://www.fishbase.org (version 01/2016). GOLDSPINK, C. R. 1978. Comparative observations on the growth rate and year class strength of roach Rutilus rutilus L. in two Cheshire lakes, England. J. Fish Biol., 12: 421-433.

GOLDSPINK ,C. R. 1979. The population density, growth rate and production of roach Rutilus rutilus (L.) the Netherlands. J. Fish Biol., 15: 473-498.

JAMET, J. L. \& F. DESMOLLES. 1994. Growth, reproduction and condition of roach (Rutilus rutilus (L.)), perch (Perca fluviatilis, L.) and ruffe (Gymnocephalus cernuus (L.)) in eutrophic Lake Aydat (France). International Review of Hydrobiology, 79(2): 305-322

LE CREN, E. D. 1951. The length-weight relationship and seasonal cycle in gonad weight and condition in perch (Perca fluviatilis). J. Animal Ecol., 20: 201-219.

MANN, R.H.K. 1973. Observations on the age, growth, reproduction and food of the roach Rutilus rutilus (L.) in two rivers in southern England. J. Fish Biol., 5: 707-736.

MATIĆ-SKOKO, S., P. TUTMAN, J. DULČIĆ, I. PRUSINA, Ž. ĐOĐO, B. GLAMUZINA. 2011. Growth pattern of the endemic Neretvan roach, Rutilus basak (Heckel, 1843) in the Hutovo Blato wetland. J. Appl. Ichth., 27: 813-819.

MOUTOPOULOS, D. K. \& K. I. STERGIOU. 2002. Length-weight and length-length relationships of fish species from the Aegean Sea (Greece). J. Appl. Ichth., 18: 200-203.

MURPHY, B. R., W. D. WILLIS \& A. T. SPRINGER. 1991. The relative weight index in fisheries management: Status and need. Fisheries, 16 (2): $30-38$.

NADDAFI, R., A. ABDOLI, B. H. KIABI, B. M. AMIRI \& M. KARAMI. 2005. Age, growth and reproduction of the Caspian roach (Rutilus rutilus caspicus) in the Anzali and Gomishan wetlands, North Iran. J. Appl. Ichth., 21: 1-6.

NIKOLSKY, G. V. 1963. The ecology of fishes. Academic Press, London and New York, 352 pp.

PAPAGEORGIOU, N. K. 1979. The length weight relationship, age, growth and reproduction of the roach Rutilus rutilus (L) in Lake Volvi. J. 
Fish Biol., 14: 529-538.

PETRIKI, O., E. GOUSIA \& D. C. BOBORI. 2010. Weight-length relationships of 36 fish species from the River Strymon system (northern Greece). J. Appl. Ichth., 31(1): 939-941.

POPE, K.L. \& C.G. KRUSE. 2001. Assessment of fish condition data. "Statistical Analyses of Freshwater Fisheries Data American Fisheries Society Publication", 74 pp

RACZYŃSKI, M., P. CZERNIEJEWSKI, M. WITKOWSKA \& B. KIRIAKA. 2008. Age and growth rate of roach (Rutilus rutilus L.) from 3 lakes used for recreational fishing. Teka Komisji Ochrony i Kształtowania Środowiska Przyrodniczego O.L. Pan, 5a: 106-116.

RICKER, W. E. 1975. Computation and interpretation of biological statistics of fish populations. Fish. Research Board Can., Bulletin No. 191 191: 203-219.

STOESSEL, J. D. 2014. Age, growth, condition and reproduction of roach Rutilus rutilus (Teleostei: Cyprinidae), in south-eastern Australia. Mar. and Fresh. Res., 65: 275-281.
TARKAN, A. S. 2006. Reproductive ecology of two cyprinid fishes in anoligotrophic lake near the southern limits of their distribution range. Ec. Fresh. Fisheries, 15: 131-138.

TSOUMANI, M., A. P. APOSTOLIDIS \& I. D. LEONARDOS. 2012. Length-weight relationships of Rutilus species from fifteen Greek lakes. J. Appl. Ichthyology, 29(1): 1-2.

TUTMAN, P., MATIĆ-SKOKO, S., HAMZIĆ, A., HASKOVIĆ, E., PAVLIČEVIĆ, J., DULČIĆ, J., GLAMUZINA, B., 2018. Life history traits of the Neretva roach Rutilus basak (Heckel, 1843) (Pisces, Cyprinidae): biological-ecological contribution for biodiversity conservation of freshwater fish. Croat. J. Fish., 76 (2): 66-71. WOOTTON, R. J. 1999. Fish Ecology. Chapman and Hall, New York, 212 p.

ZAR, J. H. 1999. Biostatistical analysis. (Fourth Edition). Prentice Hall, Upper Saddle River, $207 \mathrm{pp}$. 


\title{
Dužinsko-maseni odnos crvenoperke Rutilus rutilus (Linnaeus, 1758) u jezeru Volvi (sjeverna Grčka)
}

\author{
Stavroula KYRITSI ${ }^{*}$ i Antonis K. KOKKINAKIS ${ }^{2}$ \\ *Kontakte-pošta: stakir@ap.teithe.gr
}

\begin{abstract}
SAŽETAK
Procijenjeni su odnosi duljine i težine (LWR) i različiti indeksi uvjeta za crvenperku u jezeru Volvi (sjeverna Grčka). Rezultati su pokazali da je ženka crvenperke iz jezera Volvi jednake dužine kao i primjerci iz cijelog svijeta teža nego u drugim područjima širom svijeta. Također, ženke su pokazivale veću težinu od mužjaka iste duljine.

Značajne razlike $(\mathrm{P}<0,05) \mathrm{LWR}$-a također su bile između spolova, ovisno o mjesecu. Clarkov kondicijski čimbenik dosegnuo je vrhunac krajem ljeta, ne pokazujući značajnu razliku između spolova, dok su ostala tri procijenjena čimbenika stanja (alometrija, Fulton, Le Cren) dosegla vrhunac zimi. Procjena različitih zastupljenih faktora stanja prema spolu može smanjiti nesigurnost koja se javlja procjenom rasta ribe.
\end{abstract}

Ključne riječi: sezonska varijabilnost, spolno specifična, Fultonov indeks, bočate vode, Grčka 